\title{
ANALISIS MOTIVASI KERJA DAN DISIPLIN KERJA TERHADAP KINERJA KARYAWAN PADA PT. CONCORD INDUSTRI KARAWANG \\ (Penelitian di PT. Concord Industri Karawang di Desa Cimahi Kecamatan Klari Kabupaten Karawang)
}

\author{
Sari Marliani \\ Thomas Nadeak
}

\begin{abstract}
The purpose of this research is (a) to analyze and explain the effect simultaneously and partially between work motivation variables, work discipline variables and employee performance variables at PT. Concord Industries Karawang. The type of research used is explanatory with a quantitative approach with the population in this study is 200 employees with a sample of 50 employees. Data analysis in this study used multiple linear regression analysis and processed with SPSS 22.00 for windows. (b) to test the results of the Sig value hypothesis. $F \leq \alpha=0.05(0,000 \leq 0.05)$ which means that there is a simultaneous significant influence of the variables of work motivation and work discipline on employee performance variables and known value of Sig.t $\alpha \alpha=0.05(0.001$ $\leq 0,05)$ for work motivation on employee performance and Sig.t value t $\alpha=0.05(0,000 \leq$ 0.05) for work discipline on employee performance which means it shows a partially significant effect of employee work motivation and employee work discipline variables on performance the employee.
\end{abstract}

Keywords: Work Motivation, Work Discipline, Employee Performance. 


\begin{abstract}
ABSTRAK
Tujuan dilakukannya penelitian ini adalah (a) untuk menganalisis dan menjelaskan pengaruh secara simultan dan parsial antara variabel motivasi kerja, variabel disiplin kerja dan variabel kinerja karyawan pada PT. Concord Industri Karawang. Jenis penelitian yang digunakan bersifat penjelasan dengan pendekatan kuantitatif dengan jumlah populasi pada penelitian ini adalah 200 karyawan dengan sampel 50 karyawan. Analisis data pada penelitian ini menggunakan analisis regresi linier berganda dan diolah dengan program SPSS 22.00 for windows. (b) untuk menguji hasil dari hipotesis nilai Sig. F $\leq \alpha=0,05(0,000 \leq$ $0,05)$ yang artinya bahwa ada pengaruh signifikan secara simultan dari variabel motivasi kerja dan Disiplin kerja terhadap variabel kinerja karyawan dan diketahui nilai Sig.t $\leq \alpha=$ $0,05(0,001 \leq 0,05)$ untuk motivasi kerja terhadap kinerja karyawan dan nilai Sig.t $\leq \alpha=0,05$ $(0,000 \leq 0,05)$ untuk disiplin kerja terhadap kinerja karyawan yang artinya menunjukkan pengaruh signifikan secara parsial dari variabel motivasi kerja karyawan dan disiplin kerja karyawan terhadap kinerja karyawan.
\end{abstract}

Kata Kunci : Motivasi Kerja , Disiplin Kerja , Kinerja Karyawan.

\title{
Latar Belakang Masalah
}

Kinerja adalah suatu prestasi kerja dari pencapaian setiap karyawan dalam melaksanakan tugasnya dengan penuh rasa tanggung jawab yang di berikan oleh perusahaan. Oleh sebab itu kinerja sangatlah penting bagi perusahaan karena dengan kinerja perusahaan akan mempunyai kualitas sumber daya manusia yang handal sehingga akan menghasilkan dan meningkatkan produk yang unggul baik dari kualitas dan kuantiitas maupun efektivitas dan efisiensi yang akan berdampak positif bagi tujuan perusahaan.

Menurut Mangkunegara (2012:9) “Kinerja karyawan (prestasi kerja) adalah hasil kerja secara kualitas dan kuantitas yang dicapai oleh seorang karyawan dalam melaksanakan tugasnya sesuai dengan tanggung jawab yang diberikan kepadanya”. Sedangkan menurut August W. Smith dalam Sedarmayanti (2009:50) bahwa kinerja adalah "hasil atau ukuran dari suatu proses atau pencapaian/prestasi seseorang berkenaan dengan tugas-tugas yang dibebankan kepadanya".

Terdapat beberapa faktor yang mempengaruhi kinerja karyawan dalam menyelesaikan pekerjaannya yaitu: (1) karakteristik situasi, (2) deskripsi pekerjaan, spesifikasi pekerjaan, dan standar kinerja pekerjaan, (3) tujuan-tujuan penilaian kinerja, dan (4) sikap para 
karyawan dan manajer terhadap evaluasi. Salah satu faktor yang mempengaruhi loyalitas karyawan adalah kepuasan kerja karyawan.

Selain itu, faktor lain yang harus diperhatikan adalah motivasi bekerja karyawannya. Motivasi adalah kemauan untuk memberikan upaya lebih untuk meraih tujuan organisasi, yang disebabkan oleh kemauan untuk memuaskan kebutuhan individual (Robbins, 2001:198). Adanya motivasi yang tepat para karyawan akan terdorong untuk berbuat semaksimal mungkin dalam melaksanakan tugasnya karena meyakini bahwa dengan keberhasilan organisasi dalam mencapai tujuan dan berbagai sasarannya, kepentingan- kepentingan pribadi para anggota organisasi tersebut akan tercakup pula.

Dengan motivasi yang tinggi akan menciptakan sebuah komitmen terhadap apa yang menjadi tanggung jawabnya dalam menyelesaikan setiap pekerjaan. Motivasi kerja akan memberikan gairah dalam bekerja. Dengan pemberian motivasi kerja dimaksudkan pemberian daya perangsang dan dorongan yang signifikan kepada karyawan yang bersangkutan agar karyawan tersebut bekerja dengan segala upayanya. Untuk meningkatkan motivasi kerja karyawan dalam organisasi di perusahaan diperlukan lingkungan kerja dan sebuah team work yang kondusif guna mendorong terciptanya sikap dan tindakan yang profesional dalam menyelesaikan pekerjaan sesuai dengan bidang dan tanggung jawab masing - masing karyawan ,

Faktor-faktor yang dapat digunakan untuk meningkatkan kinerja pegawai , diantaranya disiplin kerja. Dalam meningkatkan kinerja sebuah perusahaan . kedisiplinan karyawan dituntut untuk lebih baik dalam pencapaian produktivitas perusahaan dalam memperoleh profit semaksimal mungkin. Oleh karena itu tanpa ada kinerja yang baik dari karyawan maka perusahaan tidak akan mencapai goal yang diinginkannya . karyawan adalah asset perusahaan yang harus di prioritaskan dari berbagai hal baik, kesehatan, keamanan bekerja, gaji, perumahan dan pendidikan dan masa pensiun.

Disiplin kerja. adalah keadaan ideal dalam mendukung pelaksanaan tugas sesuai aturan dalam rangka mendukungoptimalisasi kerja. Bagaimanapun salah satu syarat agar disiplin dapat ditumbuhkan dalam lingkungan kerja ialah, adanya pembagian kerja 
yang tuntas sampai kepada karyawan yang paling bawah, sehingga setiap orang tahu dengan sadar apa tugasnya masing-masing, bagaimana melakukannya, kapan pekerjaan dimulai dan selesai, seperti apa hasil kerja yang disyaratkan, dan kepada siapa mempertanggung jawabkan hasil pekerjaannya . Untuk itu kedisiplinan harus ditumbuh kembangkan agar tumbuh pula ketertiban dan kefektifan dan efisien. Dengan kedisiplinan akan melahirkan sosok pemimpin atau karyawan yang baik dalam meningkatkan kredibilitas dan profitabilitas perusahaan .

PT. Concord Industri Karawang yang baru berdiri pada tahun 2015 merupakan perusahaan milik pemerintah Modal Asing (PMA) yang bergerak dibidang manufaktur. Perusahaan PT. Concord Industri Karawang adalah perusahaan yang memproduksi keramik unggulan yang dipasarkan di Indonesia. Dampak yang timbul didirikannya perusahaan ini adalah hampir sebagian karyawan di peroleh dari daerah sekitar dusun cimahi, sehingga mampu membantu perekonomian masyarakat wilayah sekitar khususnya masyarakat Kabupaten Karawang dan mendorong perekonomian dan pembangunan daerah disegala bidang serta sebagai salah satu sumber pendapatan daerah dalam rangka meningkatkan taraf hidup masyarakat di wilayah dusun Cimahi dan khususnya masyarakat Kabupaten Karawang. Dengan demikian PT. Concord Industri Karawang dapat membantu pemerintah Kabupaten Karawang dalam menciptakan lapangan pekerjaan untuk mewujudkan kesejahteraan masyarakat Karawang melalui peningkatan perekonomian dan kualitas sumberdaya manusia yang lebih baik.

Dalam melakukan penelitian di PT. Concord Industri Karawang adalah masih kurangnya karyawan yang memiliki kinerja yang baik. Ini dikarenakan hampir dari sebagian karyawan adalah penduduk sekitar dusun cimahi yang berpendidikan SD dan SMP. Dari latar pendidikan tersebut sangat berpengaruh kepada kinerja yang dihasilkan oleh setiap karyawan.

Dari latar pendidikan tersebut sangat berpengaruh kepada kinerja yang dihasilkan oleh setiap karyawan. Masih banyak karyawan yang tidak memiliki tingkat kesadaran untuk berdisiplin yang mengindikasikan tingkat kesadaran untuk berdisiplin dari setiap masingmasing karyawan masih kurang. Banyak karyawan yang sesuka hati masuk tidak di jam yang sudah ditentukan dan tidak melakukan absen walaupun sudah dengan system absen 
finger, ditambah lagi dalam melakukan pekerjaan, banyak karyawan tidak sesuai prosedur dan aturan yang sudah ditetapkan oleh perusahaan. Karyawan seperti tidak mempunyai motivasi kerja yang jelas, padahal perusahaan sudah memberikan fasilitas dan upah yang baik - perusahaan terus berupaya agar karyawan merasa nyaman dan termotivasi untuk bekerja lebih giat dan disiplin kerja yang baik supaya pencapaian tersebut menunjukkan bahwa kinerja perusahaan mengalami peningkatan dari waktu ke waktu.

Berikut ini data temuan disiplin kerja karyawan di PT Concord Industri Ka raw ang tahun 2015 dengan jumlah karyawan 200 orang.

\section{Tabel 1.1}

Data Absen Karyawan PT Concord Industri Karawang Tahun 2015-2016

\begin{tabular}{|c|c|c|c|c|c|c|c|c|c|c|}
\hline \multirow[b]{2}{*}{ No } & \multirow[b]{2}{*}{ Bulan } & \multicolumn{2}{|c|}{ Ijin } & \multicolumn{2}{|c|}{ Tidak Ijin } & \multicolumn{2}{|c|}{$\begin{array}{l}\text { Keluar } \\
\text { Kantor }\end{array}$} & \multicolumn{3}{|c|}{ Tidak Masuk Kantor } \\
\hline & & DT & PC & DT & $\mathbf{P C}$ & Ijin & $\begin{array}{l}\text { Tdk } \\
\text { Ijin }\end{array}$ & Ijin & Sakit & Alpa \\
\hline 1 & Januari & 20 & 12 & 20 & 3 & 10 & 6 & 14 & 40 & 10 \\
\hline 2 & Februari & 13 & 6 & 10 & 1 & 13 & 8 & 0 & 15 & 12 \\
\hline 3 & Maret & 15 & 7 & 17 & 5 & 10 & 10 & 7 & 6 & 0 \\
\hline 4 & April & 12 & 3 & 16 & 2 & 16 & 6 & 15 & 6 & 11 \\
\hline 5 & Mei & 20 & 6 & 11 & 4 & 12 & 4 & 7 & 3 & 7 \\
\hline 6 & Juni & 16 & 12 & 20 & 7 & 9 & 4 & 9 & 17 & 9 \\
\hline 7 & Juli & 10 & 10 & 15 & 2 & 10 & 0 & 5 & 20 & 8 \\
\hline 8 & Agustus & 15 & 10 & 5 & 1 & 10 & 7 & 52 & 5 & 0 \\
\hline 9 & September & 8 & 13 & 3 & 1 & 10 & 2 & 7 & 15 & 5 \\
\hline 10 & Oktober & 12 & 18 & 3 & 4 & 10 & 5 & 0 & 23 & 6 \\
\hline 11 & Nopember & 10 & 14 & 2 & 3 & 10 & 9 & 4 & 50 & 8 \\
\hline 12 & Desember & 10 & 15 & 4 & 4 & 10 & 19 & 17 & 60 & 15 \\
\hline
\end{tabular}

Sumber: HRD PT Concord Industri Karawang , 2015-2016

Keterangan:

DT

: Datang Terlambat

PC

: Pulang Cepat 
Mengacu pada uraian di atas maka perlu dilakukan penelitian yang sesuai dengan permasalahan tersebut, Adapun judul yang sesuai untuk penelitian ini adalah “Analisis Motivasi Kerja dan Disiplin Kerja terhadap Kinerja Karyawan (Studi pada Karyawan PT . Concord Industri Karawang)"

\section{A. Batasan Masalah}

Karena keterbatasan waktu, biaya, tenaga dan sarana, pembahasan tentang kinerja karyawan ternyata banyak sekali factor-faktor yang mempengaruhinya, oleh sebab itu perlu adanya pembatasan masalah . Agar penelitian terfokus maka masalah akan dibatasi dengan 3 variabel yaitu kinerja karyawan $(\mathrm{Y})$ sebagai variabel terikat, motivasi kerja $\left(\mathrm{X}_{1}\right)$ dan disiplin kerja karyawan $\left(\mathrm{X}_{2}\right)$ sebagai variabel bebas.

\section{Perumusan Masalah}

Berdasarkan latar belakang masalah tersebut, peneliti membuat rumusan masalah penelitian sebagai berikut:

1. Apakah terdapat pengaruh Motivasi kerja terhadap Kinerja di PT. Concord Industri Karawang ?

2. Apakah terdapat pengaruh Disiplin kerja karyawan terhadap Kinerja karyawan di PT. Concord Industri Karawang?

3. Apakah terdapat pengaruh Motivasi kerja dan Disiplin kerja karyawan secara bersama-sama terhadap Kinerja karyawan di PT. Concord Industri Karawang?

\section{TINJAUAN PUSTAKA}

\section{Pengertian Motivasi}

"Motivasi adalah kondisi mental yang mendorong dilakukannya suatu tindakan (action atau activities) dan memberikan kekuatan (energy) yang mengarah kepada pencapaian kebutuhan, memberi kepuasan ataupun mengurangi ketidaksimbangan”. (Martoyo (2007:183)

Motivasi menurut Kamus Besar Bahasa Indonesia (KBBI), (2008: 930) adalaah dorongan yang timbul pada diri seseorang sadar atau tidak sadar untuk 
melakukan suatu tindakan dengan tujuan tertentu, atau usaha-usaha yang dapat menyebabkan seseorang atau sekelompok orang tertentu bergerak melakukan sesuatu karena ingin mencapai tujuan yang dikehendaki.

Teori motivasi yang dikembangkan oleh Abraham H. Maslow (Teori Kebutuhan) (Winardi, 2001:69-93) pada intinya berkisar pada pendapat bahwa manusia mempunyai lima dimensi dengan indicator yaitu :

a) Kebutuhan fisiologikal (physiological needs); pekerjaan yang sesuai dengan keahlian, mengatasi tekanan dalam pekerjaan, gaji yang sesuai dengan keahlian, mengatasi kesukaran dalam bekerja, rasa memiliki

b) Kebutuhan rasa aman (safety needs) ; lingkungan kerja yang kondusif, kenyaman dalam bekerja, jaminan keamanan dalam bekerja.

c) Kebutuhan akan Sosial (social needs); dapat berkomunikasi dengan seluruh pegawai, dapat bersosialisasi dengn rekan sekerja, mendapatkan promosi kerja, kenaikan pangkat.

d) Kebutuhan akan harga diri (esteem needs); mendapatkan pengakuan dari rekan kerja, mendapatkan pujian dari atasan, mendapatkan bonus.

e) Aktualisasi diri (self actualization) ; mendapatkan peluang untuk maju, dapat dipercaya, persaingan yang sehat, kreativ bekerja, mampu mengembangkan karir.

Dari uraian diatas dapat kita garis bawahi motivasi merupakan suatu faktor yang mendorong seseorang untuk melakukan suatu aktivitas tertentu untuk mencapai tujuan, oleh karena itu motivasi mempunyai pengaruh yang cukup besar terhadap kinerja , karena jika karyawan termotivasi maka dengan sendirinya , karyawan akan bekerja lebih semangat, lebih giat dan loyalitas akhirnya akan menghasilkan produktivitas yang tinggi.

\section{A. Pengertian Disiplin}

Menurut Davis dalam Mangkunegara (2008:129) mengemukakan bahwa 'Dicipline is management action to enforce organization standards.' Disiplin kerja dapat diartikan sebagai pelaksanaan manajemen untuk memperteguh pedoman-pedoman organisasi. 
Sedangkan menurut Soegeng Prijodarminto dalam Sudrajat (2008:1) bahwa 'disiplin adalah suatu kondisi yang tercipta dan terbentuk melalui proses dari serangkaian perilaku yang menunjukkan nilai-nilai ketaatan, kepatuhan, kesetiaan, ketenteraman, keteraturan, dan ketertiban'.

Konsep disiplin kerja dikembangkan oleh Novitasari (2008:13) dalam dimensi disiplin kerja adalah sebagai berikut:

a. Penggunaan waktu secara efektif, meliputi :

1) Ketepatan waktu dalam melaksanakan tugas

2) Penghematan waktu dalam melaksanakan tugas

b. Ketaatan terhadap peraturan yang telah ditetapkan, meliputi :

1) Ketaatan terhadap jam kerja

2) Ketaatan terhadap pimpinan

3) Ketaatan terhadap prosedur dan metode kerja.

c. Tanggungjawab dalam pekerjaan dan tugas, meliputi :

1) Melakukan pekerjaan sesuai dengan rencana

2) Mengevaluasi hasil pekerjaan

3) Keberanian menerima resiko kesalahan

Dari uraian diatas dapat kita garis bawahi disiplin adalah suatu alat yang digunakan para manajer untuk berkomunikasi dengan karyawan agar mereka bersedia untuk mengubah suatu perilaku serta sebagai suatu upaya untuk meningkatkan kesadaran dan kesediaan seseorang mentaati semua peraturan perusahaan dan normanorma sosial yang berlaku, oleh karena itu disiplin kerja sangat berpengaruh terhadap kinerja

\section{Pengertian Kinerja}

Kinerja menurut Kamus Besar Bahasa Indonesia adalah "sesuatu yang dicapai, prestasi yang diperlihatkan, kemampuan kerja". sedangkan kata performance dalam bahasa inggris diterjemahkan kedalam bahasa Indonesia sering berbeda, sampai sekarang 
belum dibakukan. Ada yang menterjemahkan sebagai unjuk kerja, kinerja, hasil karya, karya, pelaksanaan kerja, hasil pelaksanaan kerja .

Dimensi-dimensi yang dijadikan ukuran kinerja menurut Nawawi (2000, h. 97) yaitu :

1. Tingkat kemampuan kerja (kompetensi) dalam melaksanakan pekerjaan baik yang diperoleh dari hasil pendidikan dan pelatihan maupun yang bersumber dari pengalaman kerja.

2. Tingkat kemampuan eksekutif dalam memberkan motivasi kerja, agar pekerja sebagai individu bekerja dengan usaha maksimum, yang memungkinkan tercapainya hasil sesuai dengan keinginan dan kebutuhan masyarakat.

Dimensi - dimensi yang dijadikan ukkuran kinerja menurut A. A. Anwar Prabu Mangkunegara $(2008,67)$ yaitu :

1. Hasil kerja secara kualitas

2. Kuantitas yang dicapai oleh seorang karyawan dalam melaksanakan tugasnya sesuai dengan tanggung jawab yang diberikan kepadanya.

3. Ketepatan waktu

Dimensi -dimensi yang dijadikan tolak ukur dalam kinerja menurut Robbins (2003) dalam Thoyib (2005:10) yaitu :

1. Produktivitas

2. Absensi

3. Turnover

4. Citizenship

5. satisfaction

Berdasarkan teori-teori diatas disimpulan bahwa Kinerja Karyawan adalah tindakan kerja atau pelaksanaan tugas yang telah diselesaikan oleh seseorang atau individu dalam kurun waktu tertentu dan dapat diukur dengan penuh rasa tanggung jawab. Dapat disimpulkan bahwa motivasi kerja dan disiplin kerja sangat berpengaruh terhadap kinerja , ini bisa dilihat dari pencapaian produktivitas kerja yang tinggi, 


\section{Kerangka Berfikir}

1. Pengaruh antara Motivasi Kerja $\left(\mathrm{X}_{1}\right)$ terhadap Kinerja Karyawan (Y)

Motivasi adalah dorongan atau semangat yang datangnya dari dalam diri yang dapat diaktualisasikan menjadi suatu kinerja yang baik atau tidak tergantung dari kepuasan atau ketidakpuasan yang nantinya dapat dirasakan oleh karyawan itu sendiri.

Motivasi kerja dipengaruhi oleh factor-faktor tertentu seperti : kepuasan kerja, Prestasi yang diraih, Peluang untuk maju, pengakuan orang lain, kemungkinan pengembangan karir, tanggung jawab, jelaslah dari faktor tersebut diatas motivasi kerja karyawan sangat mempengarui terhadap kinerja sehingga menghasilkan kepuasan kerja, motivasi kerja dan loyal yang ditunjukkan oleh seorang karyawan kepada tugas dan tanggung jawabnya tanpa harus dipengaruhi oleh factor apapun jelas akan lebih terlihat hasilnya.

Dari uraian tersebut dapat disimpulkan bahwa terdapat pengaruh positif yang signifikan antara motivasi kerja dengan kinerja karyawan, artinya semakin tinggi motivasi kerja karyawan maka akan semakin puas, semakin baik pula hasil kinerja karyawan di PT. Concord Industri Karawang.

\section{Pengaruh Antara Kedisiplinan Kerja Karyawan $\left(X_{2}\right)$ terhadap Kinerja Karyawan} (Y)

Pengaruh antara kedisiplinan kerja karyawan dengan kinerja karyawan adalah dipengaruhi oleh beberapa faktor internal maupun faktor eksternal yang masing-masing satu sama lain saling mempengaruhi.

Kinerja karyawan dipengaruhi oleh faktor-faktor yang mendukung diantaranya disiplin kerja. Kedisiplinan kerja adalah sikap kejiwaan dari seseorang atau kelompok orang yang senantiasa berkehendak untuk mengikuti atau memenuhi segala aturan atau keputusan yang telah ditetapkan (Sinungan,2003). Disiplin adalah prosedur yang mengoreksi atau menghukum bawahan karena melanggar peraturan atau prosedur (Simamora, 2005).

Mengacu pada uraian dan faktor-faktor apa saja yang dapat mempengaruhi disiplin kerja karyawan maka ada korelasi yang positif antara disiplin kerja dengan kinerja karyawan . 


\section{Pengaruh Motivasi Kerja $\left(X_{1}\right)$ dan Disiplin Karyawan $\left(X_{2}\right)$ terhadap Kinerja Karyawan (Y)}

Setelah diuraikan diatas bahwa keduannya antara motivasi dan Disiplin kerja karyawan terdapat pengaruh yang signifikan terhadap Kinerja Karyawan, karena faktorfaktor yang mempengaruhi kinerja karyawan adalah motivasi kerja dan disiplin karyawan. Dalam hal menjalankan tugasnya sebagai karyawan di PT. Concord Industri Karawang dengan motivasi kerja yang tinggi dan kinerja yang baik sangat berpengaruh terhadap Kedisiplinan karyawan itu sendiri. Dengan motivasi kerja , karyawan yang baik akan loyal kepada perusahaan dan membawa dampak yang baik bagi kinerja karyawan sehingga akan menghasilkan sebuah hasilkan hasil output yang optimal.

Bertolak dari uraian tersebut diatas maka antara motivasi kerja dan kedisiplinan kerja karyawan keduanya sangat besar pengaruh secara signifikan terhadap kinerja karyawan di PT. Concord Indiustri Karawang.

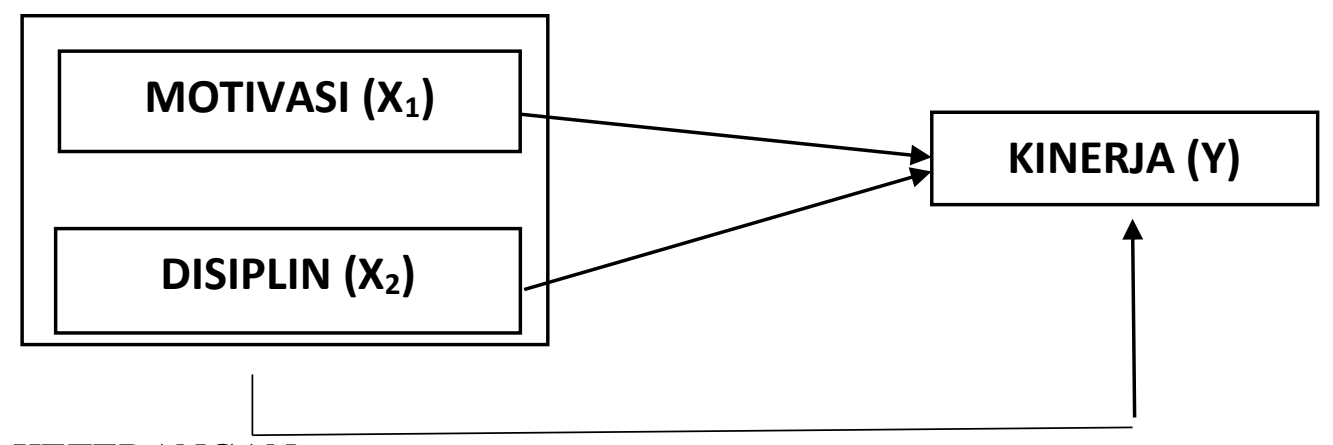

KETERANGAN :

$\mathrm{Y}=$ Variabel terikat: Kinerja Karyawan

$\mathrm{X} 1$ = Variabel bebas : Motivasi Kerja

$\mathrm{X} 2$ = Variabel bebas : Disiplin Kerja

\section{Hipotesis Penelitian}

Dengan memperhatikan deskripsi teoritik dan kerangka berfikir sebagaimana yang telah diuraikan diatas, maka hipotesis yang diajukan :

1. Di duga ada pengaruh yang positif dan signifikan motivasi kerja terhadap kinerja karyawan. 
2. Di duga ada pengaruh yang positif dan signifikan Disiplin kerja karyawan terhadap kinerja karyawan.

3. Di duga ada pengaruh yang positif dan signifikan motivasi kerja dan disiplin kerja karyawan terhadap kinerja karyawan.

\section{TUJUAN DAN MANFAAT PENELITIAN}

\section{Tujuan dan Manfaat Penelitian}

A. Tujuan Penelitian

Tujuan Penelitian

1. Untuk mengetahui seberapa besar pengaruh motivasi kerja terhadap disiplin kerja karyawan di PT. Concord Industri Karawang.

2. Untuk mengetahui seberapa besar pengaruh disiplin karyawan terhadap kinerja karyawan di PT. Concord Industri Karawang.

3. Untuk mengetahui seberapa besar pengaruh motivasi kerja dan disiplin kerja karyawan secara bersama-sama terhadap kinerja karyawan di PT. Concord Industri Karawang .

B. Manfaat Penelitian

Penelitian ini berguna untuk :

1. PT. Concord Industri Karawang dalam mengetahui seberapa besar pengaruh motivasi kerja dan disiplin kerja dalam membentuk pola pikir dan kesadaran pegawai dalam bekerja dengan baik yang efektiv dan efisien.

2. Dari hasil penelitian ini dapat dijadikan informasi bagi para pegawai dalam menerapkan dan faktor apa saja yang menjadi pengaruh terbesar terhadap kinerja karyawan di PT. Concord Industri Karawang.

3. Sebagai bahan evaluasi bagi perusahaan dalam mewujudkan kinerja perusahaan untuk meningkatkan kualitas pekerja yang handal . 


\section{METODE PENELITIAN}

\section{A. Lokasi Penelitian}

Penelitian ini dilaksanakan di PT. Concord Industri Karawang jalan Cimahi kecamatan Teluk Jambe, Selama kurang lebih 3 bulan, du mulai dari bulan juni dan berakhir pada bulan Agustus 2017, objek penelitiannya yaitu sebanyak 50 orang karyawan tetap PT. Concord Industri Karawang.

\section{B. Metode Penelitian}

Penelitian ini menggunakan metode survey dengan teknik korelasi, adapun korelasi masalahnya sebagai berikut :

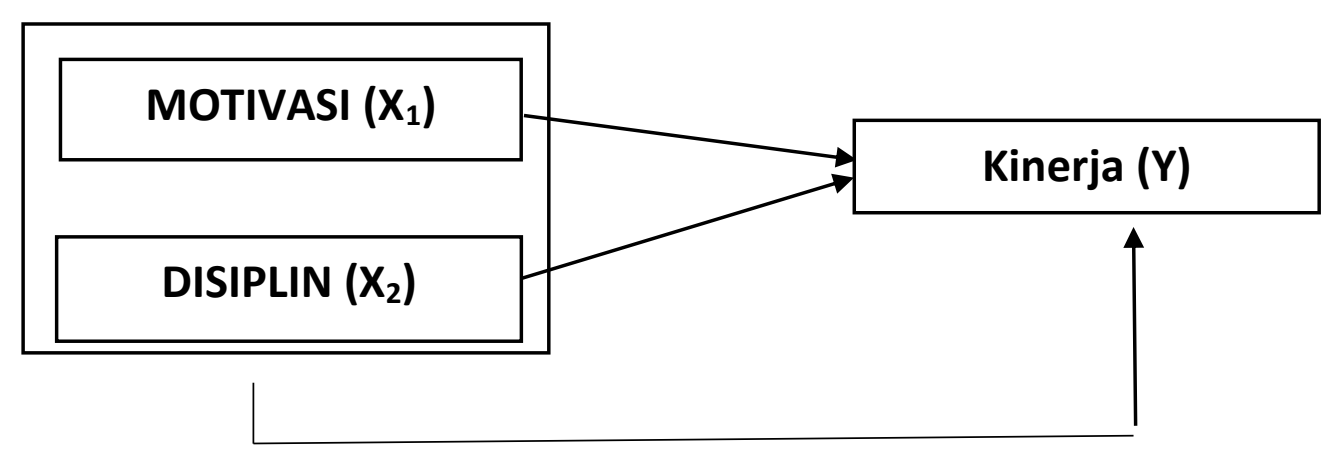

KETERANGAN :

$\mathrm{Y}=$ Variabel terikat: Kinerja Karyawan

$\mathrm{X} 1$ = Variabel bebas : Motivasi Kerja

$\mathrm{X} 2$ = Variabel bebas : Disiplin Kerja

\section{Populasi, Sampel dan teknik Pengambilan Sampel \\ a. Populasi}

Populasi adalah wilayah generalisasi yang terdiri atas :

Obyek/subyek yang mempunyai kualitas dan karakteristik tertentu yang ditetapkan oleh peneliti untuk dipelajari dan kemudian ditarik kesimpulan (Sugiono, 2005). 
Populasi penelitian ini adalah seluruh karyawan tetap berjumlah 200 orang pada PT. Concord Industri Karawang .

\section{b. Sampel}

Sampel adalah bagian atau wakil populasi yang diteliti. Sampel merupakan sebagian dari populasi yang memiliki karakteristik yang relative sama dan dianggap bias mewakili populasi (Sugiono, 2005).

Dalam menentukan sampel diperlukan suatu metode pengambilan sampel yang representative dan didapat mengambarkan keadaan populasi secara maksimal. Sampel yang diambil sebesar 25\% (Suharsini Arikunto, 2014:11). Maka dari 200 orang populasi diambil sampel sebesar $25 \%$ berjumlah 50 orang karyawan. Untuk lebih lanjut lihat cara perhitungan sebagai berikut :

Tabel 4.1

Daftar jumlah populasi dan sampel karyawan

\begin{tabular}{|c|c|c|c|}
\hline No & Uraian Jabatan & Jumlah Populasi & Jumlah Sampel \\
\hline 1 & Manager & 8 & $(8 / 200) \times 50=2$ \\
\hline 2 & Supervisor & 12 & $(12 / 200) \times 50=3$ \\
\hline 3 & Staff & 24 & $(24 / 200) \times 50=6$ \\
\hline 4 & Leader & 40 & $(40 / 200) \times 50=10$ \\
\hline 5 & Operator & 88 & $(88 / 200) \times 50=22$ \\
\hline 6 & Satpam & 12 & $(12 / 200) \times 50=3$ \\
\hline 7 & Supir & 8 & $(8 / 200) \times 50=2$ \\
\hline 8 & Pelayan & 8 & $(8 / 200) \times 50=2$ \\
\hline & Total & 200 & \\
\hline
\end{tabular}

Sumber : hasil pengolahan, 2017 


\section{c. Teknik Pengambilan Sampel}

Teknik pengambilan sampel yang digunakan dalam penelitian ini adalah proposional sampling dengan menggunakan metode stratified random sampling yaitu : a) Stratifed (Strata/tingkatan) untuk menentukan klasifikasi jabatan, b) proposional random sampling untuk menentukan jumlah sampelnya.

\section{Operasional Variabel}

a. Motivasi Kerja

Motivasi adalah dorongan dari dalam diri individu untuk melakukan sesuatu aktivitas, termasuk dalam hak bekerjauntuk mencapai tujuan.

Dimensi yang mempengaruhi motivasi kerja karyawaan terdiri dari lima dimensi yaitu : Physiological, safety and security, social, Esteem, Self-Actualization.

Berdasarkan dari teori -teori dapat disimpulkan bahwa motivasi kerja adalah dorongan dari dalam diri individu untuk melakukan sesuatu aktivitas, termasuk dalam hak bekerja untuk mencapai tujuan.

\section{b. Disiplin Kerja}

Berdasarkan dari teori-teori diatas dapat disimpulkan bahwa didiplin adalah suatu alat yang digunakan para manajer untuk berkomunikasi dengan karyawan agar mereka bersedia untuk mengubah suatu perilaku serta sebagai suatu upaya untuk meningkatkan kesadaran dan kesediaan seseorang mentaati semua peraturan perusahaan dan norma-norma sosial yang berlaku atau bisa kita artikan pula bahwa disiplin adalah factor pendorong atas perilaku seseorang untuk mencapai tujuan, tentu saja hal ini bersifat berbeda antara satu individu dengan individu yang lain.

Dimensi yang mempengarui disiplin kerja Karyawan adalah 1. Penggunaan waktu yang efektif meliputi a) ketepatan waktu dalam melaksanakan tugas ; b) penghematan waktu dalam melaksanakan tugas , 2. Ketaatan terhadap peraturan yang telah ditetapkan meliputi : a) Ketaatan terhadap jam kerja , b) Ketaatan terhadap pimpinan, c) Ketaatan terhadap prosedur dan metode kerja , 3, Tanggung jawab dalam pekerjaan dan tugas, meliputi : a) melakukan pekerjaan sesuai rencana, b) mengevaluasi hasil pekerjaan , c) keberanian menerima resiko kesalahan . 


\section{c. Kinerja}

Kinerja adalah tindakan kerja atau pelaksanaan tugas yang telah diselesaikan oleh seseorangatau individu dalam kurun waktu tertentu dan dapat diukur dengan penuh rasa tanggung jawab.

Dimensi yang mempengaruhi kinerja adalah : Kualitas, kuantitas, dan ketepatan waktu. Dan indikatornya adalah : menguasai pekerjaan, pelatihan kerja, pengalaman kerja, rolling karyawan, penampilan menarik, wawasan berpikir, efisiensi waktu, bertanggung jawab, gaji yang sesuai, hasil kerja, pujian, dapat di percaya, inovativ, imaginasi, kreativitas, absensi, penyelesaian pekerjaan, peraturan perusahaan, pencapaian kerja.

\section{Intrumen Penelitian}

Pada instrument penelitian yang digunakan adalah intrumen baku yang disusun berdasarkan definisi konseptual dan operasional dari masing-masing variabel penelitian. Tiap -tiap variable dilengkapi dengan alternative pilihan yang disediakan tiap butir pertanyaan dalam instrument penelitian yang digunakan.

Untuk lebih jelasnya dapat dilihat pada tabel dibawah ini :

Tabel 4.2

Instrument Variabel Motivasi

\begin{tabular}{|c|c|c|c|c|}
\hline No & $\begin{array}{l}\text { Variabel } \\
\text { Penelitian }\end{array}$ & Dimensi & Indikator Penelitian & $\begin{array}{l}\text { Nomor } \\
\text { pertanyaan }\end{array}$ \\
\hline 1 & Motivasi & $\begin{array}{l}\text { 1. Psikologi } \\
\text { 2. Rasa Aman }\end{array}$ & $\begin{array}{l}\text { 1. Pekerjaan yang sesuai } \\
\text { dengan keahlian. } \\
\text { 2. Mengatasi tekanan } \\
\text { dalam pekerjaan. } \\
\text { 3. Gaji yang sesuai } \\
\text { dengan keahlian. } \\
\text { 4. Mengatasi kesukaran } \\
\text { dalam bekerja. } \\
\text { 5. Rasa memiliki. } \\
\text { 1. Lingkungan kerja yang } \\
\text { kondusif. }\end{array}$ & $\begin{array}{l}1 \\
2 \\
3 \\
4 \\
5\end{array}$ \\
\hline
\end{tabular}




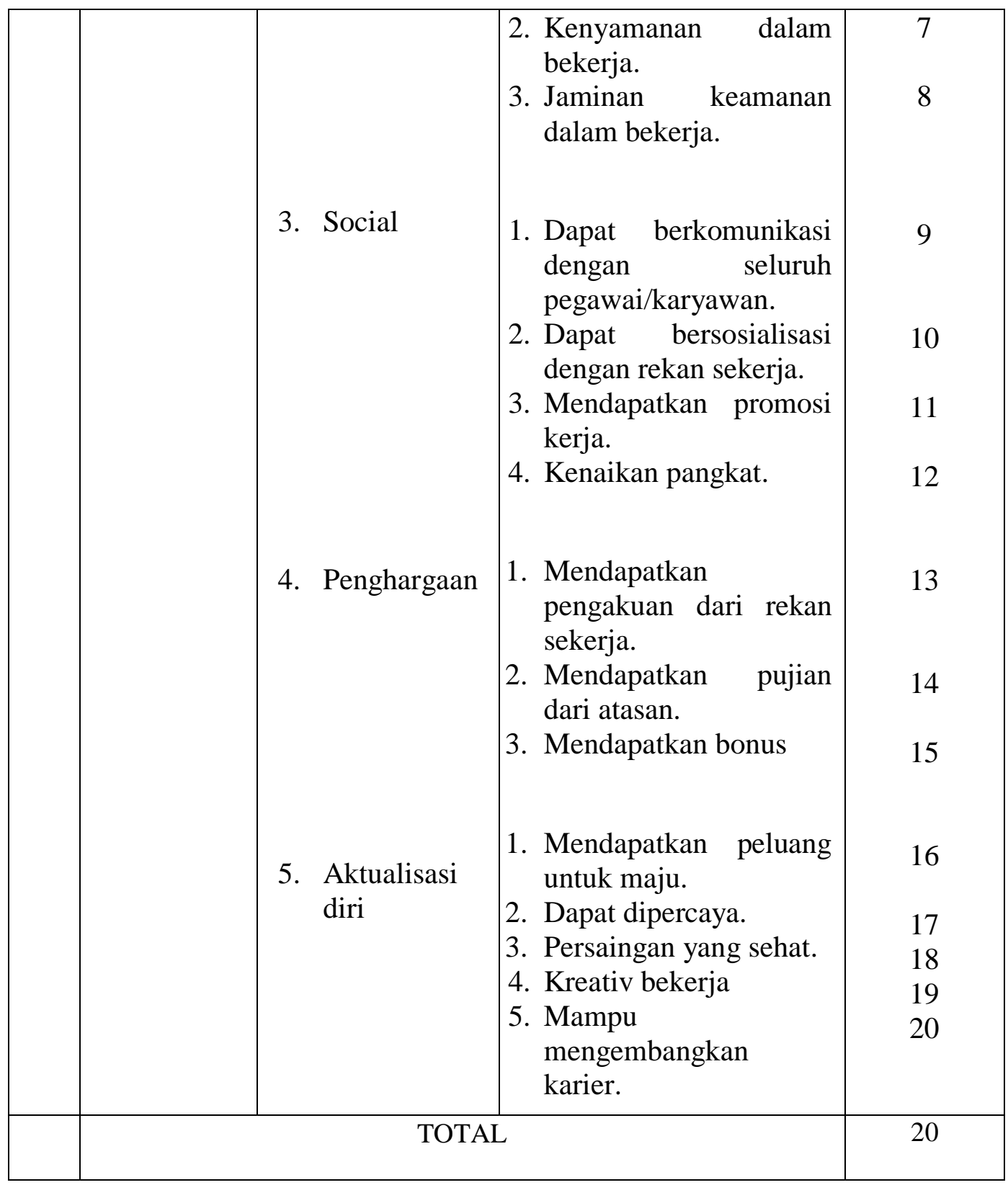

Sumber : Teori Abraham H. Maslow (teori kebutuhan)(winardi, 2001;69-93)

Tabel 4.3

Instrument Variabel Disiplin

\begin{tabular}{|l|l|l|l|l|}
\hline No & $\begin{array}{l}\text { Variabel } \\
\text { Penelitian }\end{array}$ & Dimensi & Indikator Penelitian & pomor \\
pertanyaan
\end{tabular}




\begin{tabular}{|c|c|c|c|}
\hline Karyawan & $\begin{array}{l}\text { 2. Ketaatan } \\
\text { terhadap } \\
\text { peraturan yang } \\
\text { telah } \\
\text { ditetapkan } \\
\\
\\
\text { 3. Tanggung } \\
\text { jawab dalam } \\
\text { pekerjaan dan } \\
\text { tugas, }\end{array}$ & $\begin{array}{l}\text { 2. Penghematan waktu } \\
\text { dalam melaksanakan } \\
\text { tugas, } \\
\text { 3. Ketaatan terhadap jam } \\
\text { kerja, } \\
\text { 4. } \begin{array}{l}\text { Ketaatan terhadap } \\
\text { pimpinan, }\end{array} \\
\text { 5. } \begin{array}{l}\text { Ketaatan terhadap } \\
\text { prosedur dan metode } \\
\text { kerja, }\end{array} \\
\text { 6. Melakukan pekerjaan } \\
\text { sesuai rencana, } \\
\text { 7. Mengevaluasi hasil } \\
\text { pekerjaan, hen } \\
\text { 8. Keberanian menerima } \\
\text { resiko kesalahan. }\end{array}$ & $\begin{array}{l}6 \\
7\end{array}$ \\
\hline \multicolumn{3}{|c|}{ TOTAL } & 8 \\
\hline
\end{tabular}

Sumber : Novitasari (2008:13)

Tabel 4.4

Instrument Variabel Kinerja

\begin{tabular}{|c|c|c|c|c|}
\hline No & $\begin{array}{c}\text { Variabel } \\
\text { Penelitian }\end{array}$ & Dimensi & Indikator Penelitian & $\begin{array}{c}\text { Nomor } \\
\text { pertanyaan }\end{array}$ \\
\hline
\end{tabular}




\begin{tabular}{|c|c|c|c|c|}
\hline 3 & Kinerja & $\begin{array}{l}\text { 1. Kualitas } \\
\text { 2. Kuantitas } \\
\text { 3. Ketepatan } \\
\text { waktu }\end{array}$ & $\begin{array}{l}\text { 1. Menguasai pekerjaan. } \\
\text { 2. Pelatihan kerja. } \\
\text { 3. Pengalaman kerja. } \\
\text { 4. Rolling karyawan. } \\
\text { 5. Penampilan menarik. } \\
\text { 6. Wawasan berpikir. } \\
\text { 1. Efisiensi waktu. } \\
\text { 2. Bertanggung jawab. } \\
\text { 3. Gaji yang sesuai. } \\
\text { 4. Hasil kerja, pujian. } \\
\text { 5. Dapat dipercaya. } \\
\text { 6. Inovativ, imaginasi. } \\
\text { 7. Kreativitas. } \\
\text { 1. Absensi. } \\
\text { 2. Penyelesaian } \\
\text { pekerjaan. } \\
\text { 3. Peraturan. } \\
\text { 4. Pencapaian Kerja. }\end{array}$ & $\begin{array}{c}1 \\
2 \\
3 \\
4 \\
5 \\
6 \\
\\
7 \\
8 \\
9 \\
10 \\
11 \\
12 \\
13 \\
\end{array}$ \\
\hline & \multicolumn{3}{|c|}{ TOTAL } & 17 \\
\hline
\end{tabular}

Sumber : (Mangkunegara, 2001 dalam Koemono, 2005:28), Nawawi (2000,h.97., Brahmasari (2004:121:122). Robbins (2003)dalam Tyoyib (2005:10).

\section{HASIL DAN LUARAN PENELITIAN}

\section{A. Hasil Penelitian}

\section{a. Gambaran Objek Penelitian}

\section{Identitas Perusahaan}

PT. CONCORD INDUSTRY yang berkedudukan di Jl. Raya Kosambi- Curug KM 3,8 Dsn. Kebon Kacang Desa Cimahi Kecamatan Klari Kabupaten Karawang, bergerak dibidang Industri Keramik,dan didirikan dengan akta Notaris Stephanie Willmarta, SH. Nomor 36 tanggal 21 Februari 2011.

\section{Sejarah Singkat PT. Concord Industri Karawang}


PT. CONCORD INDUSTRY yang berkedudukan di Jl. Raya KosambiCurug KM 3,8 Dsn. Kebon Kacang Desa Cimahi Kecamatan Klari Kabupaten Karawang, bergerak dibidang Industri Keramik,dan didirikan dengan akta Notaris Stephanie Willmarta, SH. Nomor 36 tanggal 21 Februari 2011.

Keramik PT. Concord Industri adalah salah satu produsen ternama ubin keramik untuk dinding dan lantai yang berlokasi Jl. Raya Kosambi- Curug KM 3,8 Dsn. Kebon Kacang Desa Cimahi Kecamatan Klari Kabupaten Karawang , bergerak dibidang Industri Keramik,dan didirikan dengan akta Notaris Stephanie Willmarta, SH. Nomor 36 tanggal 21 Februari 2011. Telah beroperasi selama 7 tahun, menadikan keramik PT. Concord Industri sangat berpengalaman dalam memproduksi ubin keramik dengan berbagai macam ukuran dan desain dengan mengikuti perkembangan teknologi modern dan terkini yang diadopsi dari italia.

Produk yang terjamin mutunya, desain dan pengembangan produk yang terus menerus, sistem kontrol yang baik pada setiap prosesnya dan kualitas layanan pelanggan yang memuaskan, membuat keramik PT. Concord Industri berhasil meraih sertifikat dalam hal ini sistem manajemen mutu SNI sehingga tidak mengherankan jika produk ubin keramik dinding dan lantai keramik PT. Concord Industri mampu menjadi salah satu primadona keramik ubin di pasar Indonesia dan negara-negara di kawasan Asia Tenggara seperti Malaysia, Filipina, Singapura, Brunei dan negara negara dikawasan Asia Selatan, Pasipik dan Timur.

\section{Letak Geografis}

PT. CONCORD INDUSTRY yang berkedudukan di Jl. Raya Kosambi- Curug KM 3,8 Dsn. Kebon Kacang Desa Cimahi Kecamatan Klari Kabupaten Karawang,

\section{b. Hasil Kuisioner}

\section{Motivasi (X1)}


Quisioner : Analisis Motivasi Kerja dan Disiplin Kerja terhadap Kinerja Karyawan (Studi pada Karyawan PT . Concord Industri Karawang).

Petunjuk menjawab :

Untuk setiap pertanyaan dibaah ini, isilah penilaian anda (persepsi anda) tentang Analisis Motivasi Kerja dan Disiplin Kerja terhadap Kinerja Karyawan (Studi pada Karyawan PT . Concord Industri Karawang).

Mohon dijawab dengan jujur dan apa adanya .

Silahkan anda memberi tanda V pada skala yang sesuai dengan persepsi anda.

\begin{tabular}{|c|c|c|}
\hline Skala : 1 & : Sangat Tidak Setuju & : \\
\hline 2 & : Tidak Setuju & : \\
\hline 3 & : Ragu - Ragu & 㘧 \\
\hline 4 & : Setuju & \\
\hline 5 & : Sangat Setuju & : \\
\hline
\end{tabular}

Motivasi (X1)

\begin{tabular}{|c|c|c|c|c|c|c|}
\hline No & Uraian & $\begin{array}{l}\text { SS } \\
5\end{array}$ & $\begin{array}{l}\text { S } \\
4\end{array}$ & $\begin{array}{l}\mathrm{R} \\
3\end{array}$ & $\begin{array}{l}\text { TS } \\
2\end{array}$ & $\begin{array}{c}\text { STS } \\
1\end{array}$ \\
\hline 1 & $\begin{array}{l}\text { Pekerjaan sudah sesuai dengan keahlian yang } \\
\text { anda miliki. }\end{array}$ & & & & & \\
\hline 2 & $\begin{array}{l}\text { Berbagai tekanan dalam pekerjaan dapat diatasi } \\
\text { oleh karyawan. }\end{array}$ & & & & & \\
\hline 3 & $\begin{array}{l}\text { Gaji yang diterima sesuai yang diharapkan oleh } \\
\text { karyawan. }\end{array}$ & & & & & \\
\hline 4 & $\begin{array}{l}\text { Mengatasi kesukaran dalam bekerja karyawan } \\
\text { meminta bantuan dari atasan. }\end{array}$ & & & & & \\
\hline 5 & $\begin{array}{l}\text { Seluruh karyawan mempunyai rasa memiliki } \\
\text { terhadap perusahaan Concord Industri } \\
\text { Karawang. }\end{array}$ & & & & & \\
\hline 6 & $\begin{array}{l}\text { Lingkungan kerja di PT. Concord Industri } \\
\text { Karawang sangat kondusif dan stabil. }\end{array}$ & & & & & \\
\hline 7 & $\begin{array}{l}\text { Kenyamanan dalam bekerja harus dapat } \\
\text { dirasakan oleh karyawan PT. Concord Industri } \\
\text { Karawang. }\end{array}$ & & & & & \\
\hline 8 & Seluruh karyawan harus mendapatkan asuransi & & & & & \\
\hline
\end{tabular}




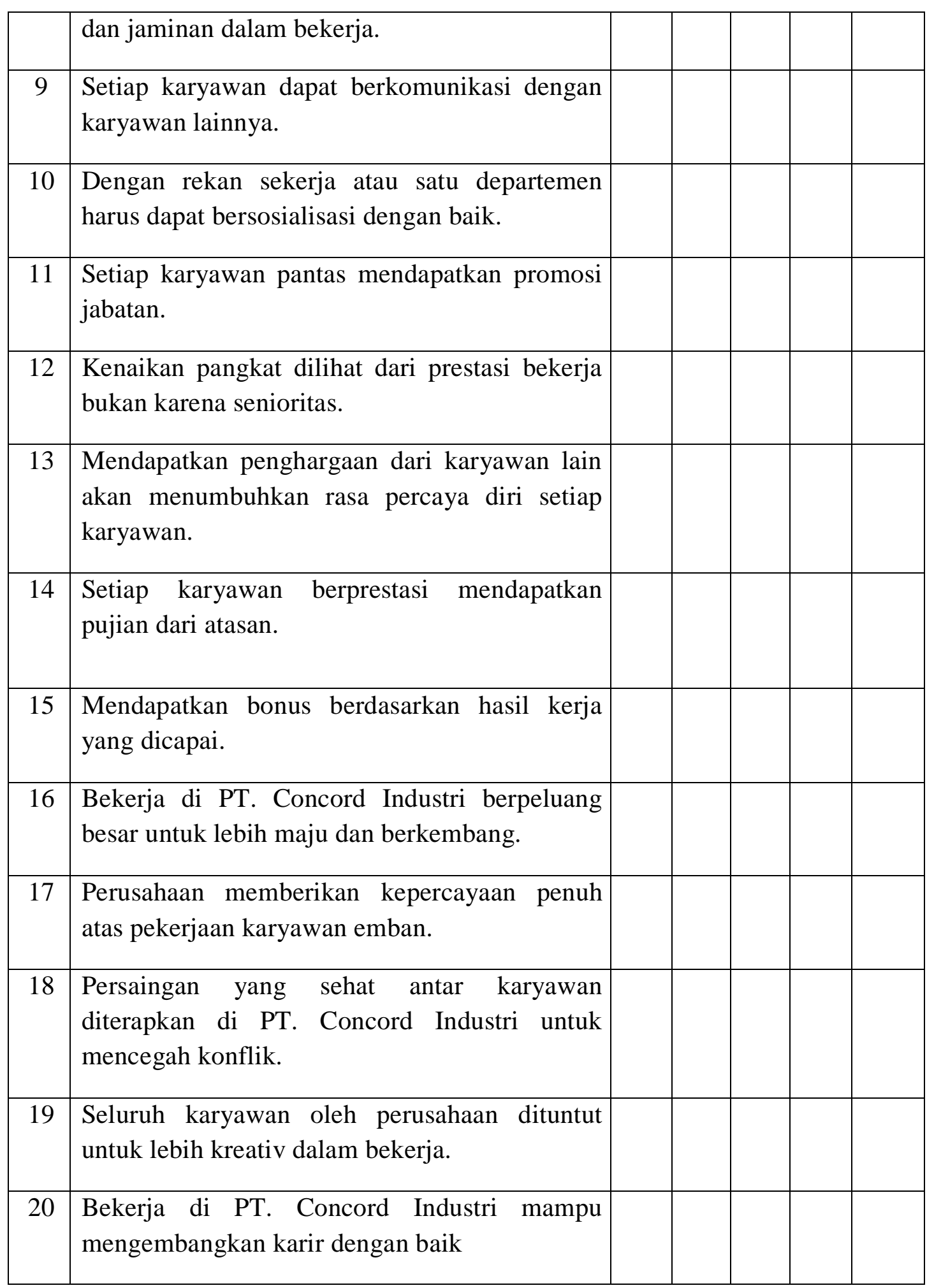

\section{Kedisiplinan (X2)}


Petunjuk menjawab :

Untuk setiap pertanyaan dibaah ini, isilah penilaian anda (persepsi anda) tentang Analisis Motivasi Kerja dan Disiplin Kerja terhadap Kinerja Karyawan (Studi pada Karyawan PT . Concord Industri Karawang).

Mohon dijawab dengan jujur dan apa adanya .

Silahkan anda memberi tanda V pada skala yang sesuai dengan persepsi anda.

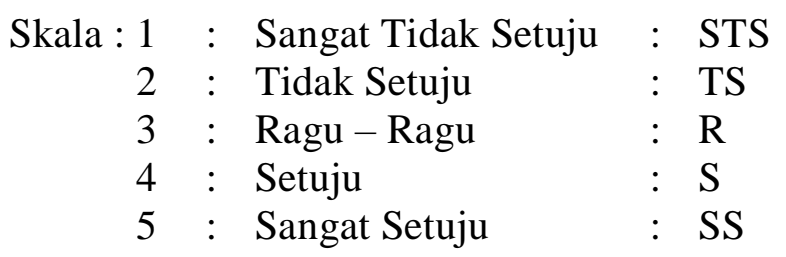

Kedisiplinan (X2)

\begin{tabular}{|c|c|c|c|c|c|c|}
\hline No & Uraian & $\begin{array}{c}\text { SS } \\
5\end{array}$ & 4 & $\begin{array}{l}\mathrm{R} \\
3\end{array}$ & $\begin{array}{c}\text { TS } \\
2\end{array}$ & $\begin{array}{c}\text { STS } \\
1\end{array}$ \\
\hline 1 & $\begin{array}{l}\text { Dalam melaksanakan pekerjaan sudah } \\
\text { ditentukan waktu penyelesaiannya. }\end{array}$ & & & & & \\
\hline 2 & $\begin{array}{l}\text { Karyawan harus tepat waktu dalam melakukan } \\
\text { pekerjaannya. }\end{array}$ & & & & & \\
\hline 3 & $\begin{array}{l}\text { Dalam bekerja penghematan waktu dalam } \\
\text { melaksanakan tugas. }\end{array}$ & & & & & \\
\hline 4 & $\begin{array}{l}\text { Dalam bekerja tidak boleh membuang waktu } \\
\text { dengan kegiatan tidak perlu. }\end{array}$ & & & & & \\
\hline 5 & Karyawan harus taat pada waktu jam bekerja. & & & & & \\
\hline 6 & $\begin{array}{l}\text { Karyawan dilarang bermalas-malasan pada saat } \\
\text { jam kerja. }\end{array}$ & & & & & \\
\hline 7 & $\begin{array}{l}\text { Seluruh karyawan harus tepat waktu pada jam } \\
\text { masuk kerja. }\end{array}$ & & & & & \\
\hline 8 & $\begin{array}{l}\text { Seluruh karyawan harus tepat waktu pada jam } \\
\text { pulang kerja. }\end{array}$ & & & & & \\
\hline 9 & $\begin{array}{l}\text { Seluruh karyawan harus taat pada pimpinan } \\
\text { perusahaan. }\end{array}$ & & & & & \\
\hline
\end{tabular}




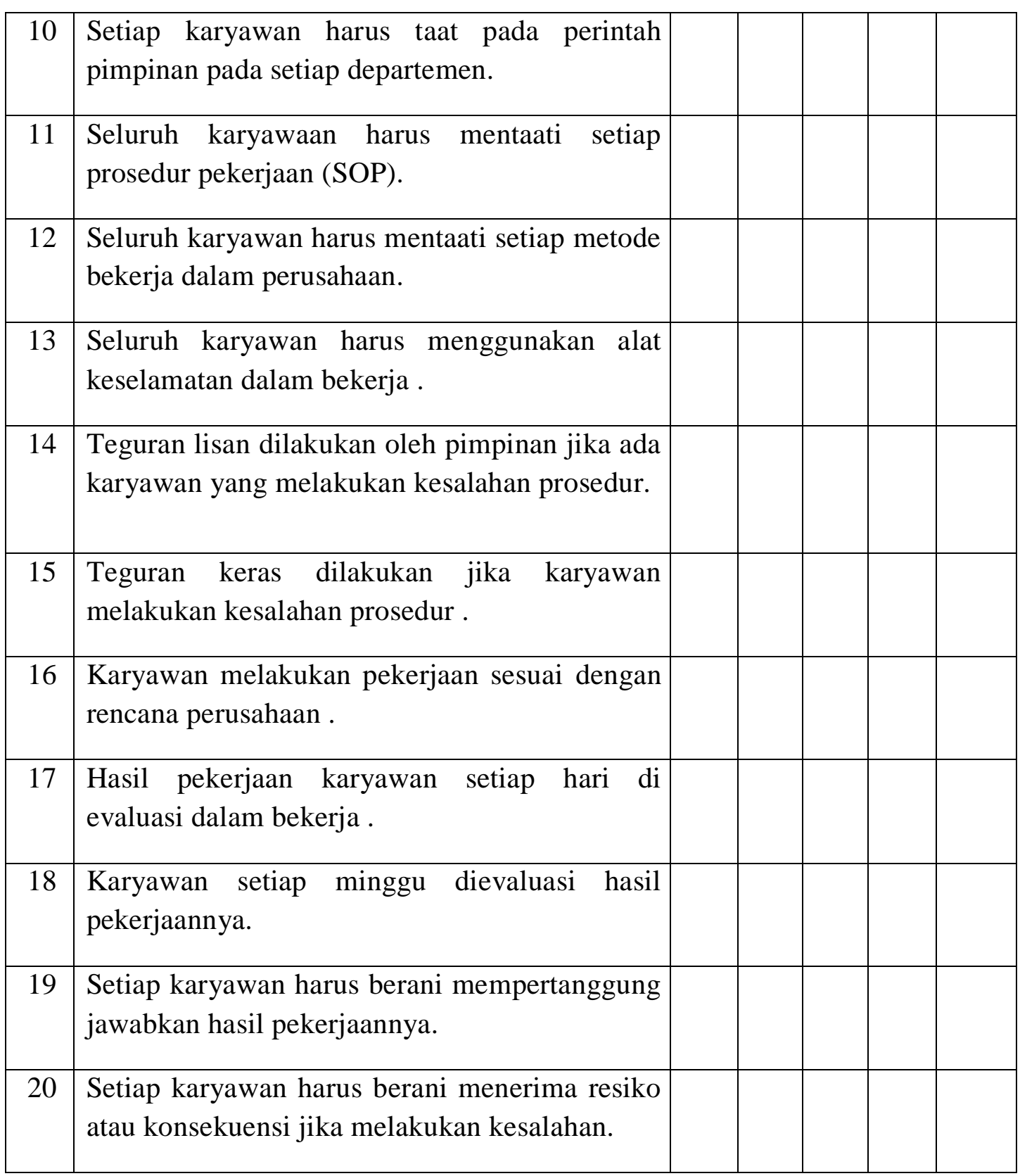

\section{Kinerja (Y)}

Petunjuk menjawab :

Untuk setiap pertanyaan dibaah ini, isilah penilaian anda (persepsi anda) tentang Analisis Motivasi Kerja dan Disiplin Kerja terhadap Kinerja Karyawan (Studi pada Karyawan PT . Concord Industri Karawang).

Mohon dijawab dengan jujur dan apa adanya . 
Silahkan anda memberi tanda V pada skala yang sesuai dengan persepsi anda.

\begin{tabular}{|c|c|c|}
\hline Skala : 1 & : Sangat Tidak Setuju & \\
\hline 2 & : Tidak Setuju & \\
\hline 3 & : Ragu - Ragu & \\
\hline 4 & : Setuju & \\
\hline 5 & : Sangat Setuju & \\
\hline
\end{tabular}

Kinerja (Y)

\begin{tabular}{|c|c|c|c|c|c|c|}
\hline No & Uraian & $\begin{array}{l}\mathrm{SS} \\
5\end{array}$ & $S$ & $\mathrm{R}$ & $\begin{array}{l}\text { TS } \\
2\end{array}$ & $\begin{array}{c}\text { STS } \\
1\end{array}$ \\
\hline 1 & $\begin{array}{l}\text { Setiap karyawan harus menguasai pekerjaan, } \\
\text { lebih terampil dan cekatan. }\end{array}$ & & & & & \\
\hline 2 & $\begin{array}{l}\text { Setiap karyawan harus diberikan pelatihan agar } \\
\text { lebih mengerti akan pekerjaannya. }\end{array}$ & & & & & \\
\hline 3 & $\begin{array}{llrr}\text { Karyawan } & \text { yang berpengalaman } & \text { harus } \\
\text { menurunkan } & \text { pengalaman kerjanya } & \text { kepada } \\
\text { yuniornya. } & & & \end{array}$ & & & & & \\
\hline 4 & $\begin{array}{l}\text { Rolling karyawan akan menambah wawasan } \\
\text { untuk lebih cakap dalam bekerja. }\end{array}$ & & & & & \\
\hline 5 & $\begin{array}{l}\text { Setiap karyawan harus berpenampilan menarik } \\
\text { dan rapi dalam bekerja. }\end{array}$ & & & & & \\
\hline 6 & $\begin{array}{l}\text { Setiap karyawan harus berwawasan dan } \\
\text { berdaya pikir untuk meningkatkan kerjanya. }\end{array}$ & & & & & \\
\hline 7 & $\begin{array}{l}\text { Seluruh karyawan harus mengefisienkan waktu } \\
\text { kerjanya semaksimal mungkin. }\end{array}$ & & & & & \\
\hline 8 & $\begin{array}{l}\text { Seluruh karyawan bertanggung jawab pada } \\
\text { pekerjaannya. }\end{array}$ & & & & & \\
\hline 9 & $\begin{array}{l}\text { Gaji yang diterima setiap bulannya sudah } \\
\text { sesuai dengan harapan karyawan. }\end{array}$ & & & & & \\
\hline 10 & $\begin{array}{l}\text { Perusahaan akan memberikan peringatan } \\
\text { kepada karyawan jika memberikan hasil kerja } \\
\text { yang buruk. }\end{array}$ & & & & & \\
\hline
\end{tabular}




\begin{tabular}{|c|c|c|}
\hline 11 & $\begin{array}{l}\text { Perusahaan akan memberikan pujian dan bonus } \\
\text { kepada karyawan jika memberikan hasil kerja } \\
\text { yang baik. }\end{array}$ & \\
\hline 12 & $\begin{array}{l}\text { Setiap karyawan harus dapat dipercaya dalam } \\
\text { bekerja dan tidak melakukan kesalahan . }\end{array}$ & \\
\hline 13 & $\begin{array}{l}\text { Persaingan antar perusahaan yang sama } \\
\text { menuntut karyawan untuk lebih inovatif dan } \\
\text { imaginasi yang tinggi. }\end{array}$ & \\
\hline 14 & $\begin{array}{l}\text { Perusahaan sangat mengharapkan karyawan } \\
\text { yang mempunyai kreativitas yang tinggi. }\end{array}$ & \\
\hline 15 & $\begin{array}{l}\text { Karyawan yang tidak pernah absen (masuk } \\
\text { terus) adalah karyawan yang berdisiplin tinggi. }\end{array}$ & \\
\hline 16 & $\begin{array}{l}\text { Karyawan yang sering kali absen dilakukan } \\
\text { teguran keras. }\end{array}$ & \\
\hline 17 & $\begin{array}{l}\text { Seluruh karyawan harus bisa menyelesaikan } \\
\text { pekerjaannya dan tidak ada pekerjaan yang } \\
\text { tertunda. }\end{array}$ & \\
\hline 18 & $\begin{array}{l}\text { Setiap peraturan harus dapat ditaati oleh } \\
\text { seluruh karyawan. }\end{array}$ & \\
\hline 19 & $\begin{array}{l}\text { Dengan peraturan karyawan lebih terkontrol } \\
\text { dalam pekerjaannya. }\end{array}$ & \\
\hline 20 & $\begin{array}{l}\text { Jabatan , promosi dan kedudukan adalah } \\
\text { pencapaian kerja yang diraih oleh setiap } \\
\text { karyawan. }\end{array}$ & \\
\hline
\end{tabular}

\section{B. Luaran Yang Di capai}

Dibawah ini luaran yang dicapai dalam penelitian ini :

\begin{tabular}{|l|l|l|l|}
\hline No & Luaran Yang dicapai & Capaian & Keterangan \\
\hline 1 & & & \\
\hline 2 & & & \\
\hline
\end{tabular}


Penelitian ini banyak sekali kekurangannya untuk itu rencana tahapan berikutnya peneliti akan mengolah data dari angket tambahan yang belum terkumpul dengan analisa SPSS dan mengambil objek penelitian yang lebih luas lagi lingkupnya.

Dari hasil perhitungan quisioner nantinya data tersebut akan diolah menggunakan metode SPSS 22. Untuk mengukur korelasi antara variabel motivasi dan displin kerja terhadap kinerja , sehingga dapat dihasilkan data yang reliable.

Adapun hasil dari output SPSS 22 adalah sebagai berikut

\begin{tabular}{|c|c|c|c|c|c|c|}
\hline \multicolumn{7}{|c|}{ Coefficients $^{a}$} \\
\hline \multirow[b]{3}{*}{ Model } & & \multirow{2}{*}{\multicolumn{2}{|c|}{ Unstandardized Coefficients }} & \multirow{3}{*}{$\begin{array}{c}\text { Standardized } \\
\text { Coefficients } \\
\text { Beta } \\
\end{array}$} & \multirow[b]{3}{*}{$\mathrm{t}$} & \multirow[b]{3}{*}{ Sig. } \\
\hline & & & & & & \\
\hline & & $\mathrm{B}$ & Std. Error & & & \\
\hline \multirow[t]{3}{*}{1} & (Constant) & 54.592 & 8.791 & & 6.210 & .000 \\
\hline & Motivasi & .042 & .127 & .053 & .333 & .741 \\
\hline & Kedisiplinan & .284 & .104 & .439 & 2.735 & .009 \\
\hline
\end{tabular}

a. Dependent Variable: Kinerja

Hasil yang didapat dari analisis SPSS akan dibuatkan dalam persamaan regresi sebagai berikut :

$\mathrm{Y}=\mathrm{a}+\mathrm{b} 1 \mathrm{x} 1+\mathrm{b} 2 \mathrm{x} 2$

$\mathrm{Y}=54592+0.042 \times 1+0.284 \times 2$

Keterangan:

$\mathrm{Y}=$ Kinerja

$\mathrm{a}=$ konstanta

b1,b2 = Koefisien Regresi

$\mathrm{x} 1=$ Motivasi

$\mathrm{x} 2=$ Kedisiplinan

Persamaan regresi diatas dapat dijelaskan : 
Konstanta sebesar 54592 artinya Jika motivasi (x1) dan Kedisiplinan (x2) nilainya 0, maka kinerja sebesar 54592.

Koefisien Regresi Variabel Motivasi (X1) sebesar 0.042 artinya, Jika Variabel Independen lain nilainya tetap dan Motivasi mengalami kenaikan 1\% maka nilai kinerja akan mengalami kenaikan sebesar 0.042 . Koefisien bernilai positif artinya terjadi hubungan positif antara motivasi dengan kinerja semakin naik motivasi maka semakin naik nilai kinerja.

Koefisien regresi variable kedisiplinan (x2) sebesar 0.284, artinya jika variable independen lain nilainya tetap, dan kinerja mengalami kenaikan 1\%, maka kinerja (Y) akan mengalami peningkatan sebesar 0.284 . Koefisien bernilai positif artinya terjadi hubungan positif antara kedisiplinan dengan nilai kinerja,semakin naik kedisiplinan maka semakin meningkat nilai kinerja.

Menurut Sugiono (2015), pedoman untuk memberikan interpretasi koefisien korelasi sebagai berikut :

$$
\begin{aligned}
& 0.0-0.199=\text { Sangat rendah } \\
& 0.20-0.319=\text { Rendah } \\
& 0.40-0.599=\text { Sedang } \\
& 0.60-0.799=\text { Kuat } \\
& 0.80-1.00=\text { Sangat Kuat }
\end{aligned}
$$

Dari hasil analisis Regresi , lampiran Output model summary dan disajikan sebagai berikut :

\begin{tabular}{ll|r|r|r} 
& & \multicolumn{2}{c}{ Model Summary } \\
Model & $\mathrm{R}$ & R Square & \multicolumn{1}{c}{$\begin{array}{c}\text { Adjusted R } \\
\text { Square }\end{array}$} & $\begin{array}{c}\text { Std. Error of the } \\
\text { Estimate }\end{array}$ \\
\hline 1 & $.473^{\mathrm{a}}$ & .224 & .191 & 2.56373 \\
\hline
\end{tabular}

\footnotetext{
a. Predictors: (Constant), Kedisiplinan, Motivasi
}

b. Dependent Variable: Kinerja

Berdasarkan table diatas diperoleh angka R sebesar 0.473. Hal ini menunjukkan bahwa terjadi hubungan yang sedang antara motivasi dan kedisiplinan terhadap kinerja pada PT. Concord Industri Karawang. Analisis Determinasi ( $\mathrm{R}^{2}$ ) 
Analisis determinasi dalam Regresi linear berganda digunakan untuk mengetahui prosentasi sumbangan pengaruh variable independen $(\mathrm{x} 1, \mathrm{x} 2)$ secara serentak terhadap variable dependen ( Y). Koefisien ini menunjukkan seberapa besar prosentase variasi variable independen yang digunakan dalam model mampu menjelaskan variasi variable dependen.

Dari hasil analisis Regresi, lihat pada out put model Summary dan disajikan sebagai berikut : Tabel hasil Analisis Determinasi

\begin{tabular}{ll|r|r|r} 
& & \multicolumn{3}{c}{ Model Summary } \\
Model & $R$ & R Square & \multicolumn{1}{c}{$\begin{array}{c}\text { Adjusted R } \\
\text { Square }\end{array}$} & $\begin{array}{c}\text { Std. Error of the } \\
\text { Estimate }\end{array}$ \\
\hline 1 & $.473^{\mathrm{a}}$ & .224 & .191 & 2.56373 \\
\hline
\end{tabular}

a. Predictors: (Constant), Kedisiplinan, Motivasi

b. Dependent Variable: Kinerja

Berdasarkan table model summary angka $\mathrm{R}^{2}$ ( R.Square ) bernilai 0.224 atau ( $22.4 \%$ ), hal ini menunjukkan bahwa prosentasi sumbangan pengaruh variable independen ( motivasi dan kedisiplinan ) terhadap variable dependen ( Kinerja ) sebesar $22.4 \%$ variasi variable independen yang digunakan dalam model ( motivasi dan kedisiplinan ) mampu menjelaskan sebesar $22.4 \%$ variasi variable kinerja. Sedangkan sisanya $77.6 \%$ dipengaruhi atau di jelaskan oleh variabel lain yang tidak dimasukkan dalam model penelitian pada perusahaan PT. Concord Industry Karawang..

Standar error of the estimate 2.56373 adalah suatu ukuran banyaknya kesalahan model regresi dalam memprediksi nilai Y, dari nilai regresi di dapat nilai 2.56373 ( satuan harga Kinerja ), hal ini berarti banyaknya kesalahan dalam memprediksi harga saham sebesar 2.56377 .

Uji Koefisien Regresi secara bersama sama ( Uji F).

Uji ini digunakan untuk mengetahui apakah variable independen $(\mathrm{x} 1, \mathrm{x} 2)$ secara bersama sama berpengaruh secara signifikan terhadap variable dependen (Y). atau untuk mengetahui apakah Model regresi dapat digunakan untuk memprediksi variable dependen atau tidak signifikan berarti hubungan yang terjadi dapat berlaku untuk populasi ( dapat digeneralisasikan ). Dari hasil output analisis Regresi dapat diketahui nilai F seperti pada table dibawah ini.

\section{ANOVA ${ }^{a}$}




\begin{tabular}{ll|r|r|r|r|r}
\hline 1 & Regression & 89.082 & 2 & 44.541 & 6.777 & $.003^{\mathrm{b}}$ \\
\hline Residual & 308.918 & 47 & 6.573 & & \\
\hline Total & 398.000 & 49 & & & \\
\hline
\end{tabular}

a. Dependent Variable: Kinerja

b. Predictors: (Constant), Kedisiplinan, Motivasi

Dari data di atas bisa diambil hipotesisnya :

Ho : Tidak ada pengaruh secara signifikan antara motivasi dan kedisplinan secara bersamaSama terhadap kinerja .

Ha : Ada pengaruh secara signifikan antara motivasi dan kedisiplinan secara bersama-sama Terhadap kinerja.

Tingkat signifikan menggunakan $\mathrm{x}=5 \%$ ( signifikasi $5 \%$ atau 0.05 adalah ukuran standar yang sering digunakan dalam penelitian.

Menentukan F Hitung

Berdasarkan tabel diperoleh F hitung sebesar 6.777

Menentukan F Tabel

Dengan menggunakan tingkat keyakinan $95 \%, x=5 \%$, DF 1 ( Jumlah Variabel )

DF $2(n-k-1)=50-2-1$

$$
=47
$$

( $\mathrm{n}$ adalah jumlah kasus dan $\mathrm{k}$ adalah jumlah variabel independen hasil di peroleh untuk $\mathrm{F}$ tabel sebesar 3.195 )

Kriteria pengujian :

Ho : Diterima bila F hitung < F, tabel

Ho : Ditolak bila F hitung $>\mathrm{F}$ tabel.

Membandingkan F hitung dengan F Tabel nilai F hitung > F tabel ( $6.777>3.195$ ) maka Ho ditolak.

Kesimpulan

Karena F hitung > F. Tabel ( $6.777>3.195$ ) maka Ho ditolak, Ha diterima artinya ada pengaruh secara signifikan antara motivasi dan kedisiplinan secara bersama-sama terhadap kinerja.

Jadi dari penelitian ini dapat disimpulkan bahwa motivasi ( x1) dan kedisplinan (x2) secara bersama-sama berpengaruh terhadap kinerja di perusahaan PT.Concord Industri Karawang. 


\section{Uji koefisien Regresi secara Parsial ( Uji T )}

Uji ini digunakan untuk mengetahui apakah dalam model regresi variabel independen $(\mathrm{x} 1, \mathrm{x} 2)$, secara parsial berpengaruh signifikan terhadap variabel dependen (Y).

Dari hasil analis regresi output dapat di sajikan sebagai berikut .

\begin{tabular}{|c|c|c|c|c|c|c|}
\hline \multicolumn{7}{|c|}{ Coefficients $^{a}$} \\
\hline \multirow[b]{3}{*}{ Model } & & \multirow{2}{*}{\multicolumn{2}{|c|}{ Unstandardized Coefficients }} & \multirow{3}{*}{$\begin{array}{c}\text { Standardized } \\
\text { Coefficients } \\
\text { Beta } \\
\end{array}$} & \multirow[b]{3}{*}{$\mathrm{t}$} & \multirow{3}{*}{ Sig. } \\
\hline & & & & & & \\
\hline & & B & Std. Error & & & \\
\hline \multirow[t]{3}{*}{1} & (Constant) & 54.592 & 8.791 & & 6.210 & .000 \\
\hline & Motivasi & .042 & .127 & .053 & .333 & .741 \\
\hline & Kedisiplinan & .284 & .104 & .439 & 2.735 & .009 \\
\hline
\end{tabular}

a. Dependent Variable: Kinerja

Langkah-langkah pengujian sebagai berikut :

Pengujian koefisien regresi variabel motivasi.

Hipotesis

Ho : Secara parsial tidak ada pengaruh signifikan antara motivasi dengan kinerja

$\mathrm{Ha}$ : Secara parsial ada pengaruh signifikan antara motivasi dengan kinerja

Tingkat signifikansi menggunakan $\mathrm{X}=5 \%$

Menentukan thitung

Berdasarkan tabel diperoleh t-hitung sebesar 0.333

Menentukan $t$ tabel

Tabel distribusi t dicari pada $\mathrm{x}=5 \%: 2=2.5 \%$ ( Uji 2 sisi $)$ dengan derajat kebebasan $(\mathrm{df})=$ n-k-1 atau 50-2-1 = 47

$\mathrm{n}$ adalah jumlah kasus dan $\mathrm{k}$ adalah jumlah variabel independen ). Dengan pengujian 2 sisi ( signifikansi $=0.025)$ hasil diperoleh untuk t tabel sebesar : 2.01174

kriteria pengujian

Terima Ho, jika t-tabel $<$ t-hitung $<$ t-tabel

Tolak Ho, jika thitung $<\mathrm{t}$ tabel atau $\mathrm{t}$ hitung $>\mathrm{t}$-tabel.

Oleh karena nilai t tabel < t hitung, maka Ho di terima artinya secara parsial tidak ada pengaruh signifikan antara motivasi dengan kinerja. Jadi dari penelitian ini dapat disimpulkan bahwa secara parsial motivasi tidak berpengaruh terhadap kinerja pada perusahaan Concord Industri Karawang. 


\begin{tabular}{|c|c|c|c|c|c|c|}
\hline \multicolumn{7}{|c|}{ Coefficients $^{a}$} \\
\hline \multirow[b]{2}{*}{ Model } & & \multicolumn{2}{|c|}{ Unstandardized Coefficients } & \multirow{2}{*}{$\begin{array}{c}\text { Standardized } \\
\text { Coefficients } \\
\text { Beta }\end{array}$} & \multirow[b]{2}{*}{$\mathrm{t}$} & \multirow[b]{2}{*}{ Sig. } \\
\hline & & $\mathrm{B}$ & Std. Error & & & \\
\hline \multirow[t]{3}{*}{1} & (Constant) & 54.592 & 8.791 & & 6.210 & .000 \\
\hline & Motivasi & .042 & .127 & .053 & .333 & .741 \\
\hline & Kedisiplinan & .284 & .104 & .439 & 2.735 & .009 \\
\hline
\end{tabular}

a. Dependent Variable: Kinerja

Pengujian variabel Kedisiplinan

Hipotesis

Ho : Secara parsial tidak ada pengaruh signifikan antara kedisiplinan dengan kinerja

Ha : Secara parsial ada pengaruh

Tingkat signifikansi menggunakan $\mathrm{x}=5 \%$

Menentukan t-hitung

Berdasarkan tabel diperoleh t-hitung sebesar 2.735

Menentukan $\mathrm{t}$-tabel

Tabel distribusi t dicari pada $\mathrm{x}=5 \%: 2=2,5 \%$ ( Uji 2 sisi ) dengan derajat kebebasan $(\mathrm{df})=$ n-k-1 atau 50-2-1 = 47

( $\mathrm{n}$ adalah jumlah kasus dan $\mathrm{k}$ adalah jumlah variabel independen ) dengan pengujian 2 sisi ( signifikansi $=0.025$ ) hasil di peroleh untuk t tabel sebesar 2,01174

Kriteria pengujian

Terima Ho jika t tabel $<\mathrm{t}$ hitung $<\mathrm{t}$ tabel

Tolak Ho jika t hitung $<\mathrm{t}$ tabel atau $\mathrm{t}$ hitung $>$ t.tabel

Oleh karena nilai t hitung > t tabel, maka tolak Ho, artinya secara parsial ada pengaruh kedisiplinan terhadap kineja karyawan. 


\section{KESIMPULAN DAN SARAN}

\section{A. KESIMPULAN}

Berdasarkan hasil penelitian bahwa Motivasi dan Kedisiplinan memberi pengaruh yang sangat signifikan terhadap kinerja karyawan pada PT. Concord Industri Karawang, tetapi secara parsial motivasi lemah dalam memberikan pengaruh terhadap Kinerja, sedangkan Kedisiplinan sangat berpengaruh kuat terhdap Kinerja pada PT. Concord Industri Karawang, oleh karena itu perlu ditingkatkan kedisiplinan dan dipertahankan agar lebih efektiv dan efisien dalam melaksanakan pekerjaannya.

\section{B. SARAN}

1. Diharapkan perusahaan untuk kedepannya harus sering mengadakan kegiatan pelatihan perdepartemen untuk meningkatkan kualitas pegawai yang kompeten di bidangnya.

2. Perusahaan memotivasi pegawainya dengan meningkatkan kesejahteraan bagi pegawai sehingga akan tercipta rasa aman bagi seluruh karyawan .

3. Perusahaan melakukan penilaian per semester untuk menilai kinerja karyawan dalam menentukan penilain promosi dan bonus bagi karyawan yang mendapatkan nilai tertinggi.

4. Kedisiplinan perlu focus utama dalam membuat penilaian dalam jenjang karir dan jenjang kepangkatan. 


\section{DAFTAR PUSTAKA}

Augustry Ferdinand, 2006. Metode Penelitian Manajemen. Semarang : Badan Penerbit Universitas Diponegoro.

Brahmasari Ida Ayu, 2004. Pengaruh Variabel Budaya Perusahaan terhadap Komitmen Karyawan dan KInerja Perusahaan Kelompok Penerbit Pers Jawa Pos, DIsertasi Universitas Airlangga.

Budiman Fransiska Maria, 2005. Pengaruh Waiabel Budaya Perusahaan terhadap KInerja Perusahaan suatu Studi pada Plaza Marina Surabaya, Tesis Universitas 17 Agustus, Surabaya.

Damanhuri Didin S., 2003. SDM Indonesia Dalam Persaingan Global, Jurnal Harian Sinar Harapan, Bogor.

Dewi Ma'rifah, 2006. Pengaruh Motivasi Kerja dan Budaya Organisasi terhadap Kinerja Pekerja Sosial pada Unit Pelaksana Teknis Dinas Sosial Propinsi Jawa Barat, http://.damanhuri.or.id.diakses tanggal 1 maret 2010.

Galih Pramon, 2004. Analisis Pengaruh Ketidakamanan Kerja terhadap Kepuasan Kerja dengan Variabel Moderator Umur dan Laman Kerja (Studi Kasus Pada Karyawan Bagian Pemasaran PT. Batik Danarhadi Surakarta. Skripsi dipublikasikan. www.digilib.uns.ac.id, diakses tanggal 09 November 2010.

Hani T Handoko, 1996. Manajemen Personalia dan Sumber Daya Manusia. Edisi 2. Yogyakarta : BPFE.

Heidi Rachman Ranupandojo dan Suad Husnan, 2002. Manajemen Personalia. Yogyakarta : BPFE.

Kreitner, Robert dan Angelo Kinicki, 2005. Perilaku Organisasi. Jakarta : Salemba Empat Luthans, Fred, 2006, Perilaku Organisasi 10 ${ }^{\text {th }}$. Edisi Indonesia. Yogyakarta : Penerbit ANDI. Malayu SP Hasibuan, 2003, Manajemen Sumber Daya Manusia, Yogyakarta : STIE YKPN Mangkunegara Anwar Prabu, 2005. Manajemen Sumber Daya Manusia Perusahaan, cetakan keenam, PT. Remaja Rosdakarya, Bandung.

Moch As'ad, 2003. Psikologi Industri. Yogyakarta : Liberty.

M. Manullang, 1981 . Manajemen Personalia, Jakarta Ghalia Indonesia

Ghozali. I. 2007. Aplikasi Analisis Multivariate dengan Program SPSS. BPFE UNDIP, Semarang 